\title{
Pharmaciana
}

Vol.11, No.1, March 2021, Page. 101-108

ISSN: 2088 4559; e-ISSN: 24770256

DOI: $10.12928 /$ pharmaciana.v11i1.18385

\section{Ointment formulation of snakehead fish (Channa striata) Extract with variations of CMC-Na and carbopol}

\author{
Mohamad Andrie*, Wintari Taurina \\ Department Pharmacy, Faculty of Medicine \\ Tanjungpura University, Pontianak, Indonesia \\ Jl. Prof. Dr. H. Hadari Nawawi, Pontianak, West Kalimantan, Indonesia
}

Submitted: 31-10-2020

Reviewed: 10-12-2020

Accepted: 27-03-2021

\begin{abstract}
Snakehead fish (Channa striata) and kelulut honey (Trigona sp.) have the potential to accelerate the wound-healing process. These natural ingredients are formulated in the form of ointment because ointment is an external medicine that is easy to apply and has long contact with the skin. Previous research has shown that the snakehead fish extract ointment undergoes phase separation, so it needs a material that can bind the snakehead fish extract and kelulut honey as the active substances in the preparation. This study aimed to determine the effect of variations in the concentration of $\mathrm{CMC}-\mathrm{Na}(3 \%, 4.5 \%, 6 \%)$ and Carbopol $(0.5 \%, 1 \%, 2 \%)$ as a binder on the ointment physical properties and to determine the best snakehead fish (Channa striata) extract ointment formulation. The ointment of snakehead fish extract was tested for organoleptic, homogeneity, spreadability, and adhesion. The test results were analyzed by One Way ANOVA with a confidence level of $95 \%$. The results showed that the higher the concentrations of CMC-Na and Carbopol used, the greater the adhesive power and the lower the spreadability. Ointment with Carbopol has a wider spreadability and a softer consistency than ointment with CMC-Na. The best formulation is shown by the Carbopol $0.5 \%$ (F4) formula, where the average spreadability with a load of $150 \mathrm{~g}$ is $5.09 \mathrm{~cm}$ and the average adhesion is 229 seconds.
\end{abstract}

Keywords: snakehead fish extract, kelulut honey, CMC-Na, carbopol

\section{*Corresponding author:}

Mohamad Andrie

Department Pharmacy, Faculty of Medicine, Tanjungpura University

J1. Prof. Dr. H. Hadari Nawawi, Pontianak, West Kalimantan, Indonesia

Email: andrie@pharm.untan.ac.id 


\section{INTRODUCTION}

Wounds are physical injuries that result in tearing and damage to skin tissue (Sabale et al., 2012). The wound will make the body respond to remove dead tissue on the skin so that the blood supply will increase and cause swelling. The basic principles of wound-healing are minimizing tissue damage, providing proper nutrition, and a humid environment to restore anatomical continuity and function of damaged tissue in a short time (Gadekar et al., 2012).

Snakehead fish (Channa striata) is a natural ingredient that has the potential to accelerate wound healing. Snakehead fish has a higher protein content (albumin) compared to other fish. Albumin is the most abundant plasma protein in the human body. In addition to snakehead fish extract, kelulut honey (Trigona sp.) also has good characteristics for wound-healing, such as antiinflammatory activity, antibacterial activity, antioxidant activity, and so on which can help to accelerate wound-healing (Gunawan, 2017). These natural ingredients in the form of ointments have been tested in vivo to provide a wound-healing effect (Andrie and Taurina, 2018). The combination of natural ingredients is expected to provide a synergistic effect so that it can be more effective in healing wounds (Andrie and Taurina, 2017). Ointments were chosen because they are the most suitable pharmaceutical preparations for medicinal purposes on the skin. After all, the contact between the drug and the skin is longer. Ointment is easy to apply and use as an external medicine (Gorada et al., 2019).

Bases are an important component which determines the quality of good or bad ointment formulation. Adeps lanae base is oily and water-free, so it stays on the skin for a long time and is expected to increase the effectiveness of the preparation when applied to the skin. Adeps lanae base also mixes easily with medicinal ingredients and stable in storage, also has consistency, softness, and neutral properties as well as the ability to spread easily on the skin. Adeps lanae is also a moisturizing agent, so it can prevent the formation of thick and hard crusts that can interfere with the process of drug penetration into the skin and interfere with the granulation and epithelialization processes that cause wound-healing to be longer (Strauer, 2008).

Gelling agent CMC-Na and Carbopol can be used as a binder in the preparation (Zulfa et al., 2017). The presence of a binder agent will increase the viscosity of the preparation. The binder agent can prevent the separation of solid particle components with liquid (dispersion medium), especially during storage (Garlen, 1996). The ointment in this study used various concentrations of CMC-Na and Carbopol to increase the viscosity of the preparation. CMC-Na is a cellulose derivative gelling agent with neutral properties and can increase viscosity well. CMC-Na functions as a gelling agent at concentrations of 3-6\%. Carbopol is a hydrophilic polymer with a polyacrylic acid structure. Carbopol functions as a gelling agent at a concentration of 0.5-2\% (Rowe et al., 2009).

Snakehead fish extract in the form of ointment is proven to be able to contain the water phase of snakehead fish extract in a greater amount than cream and gel preparations (Andrie and Taurina, 2017). Based on the optimization results of research conducted by (Gorada et al., 2019), the snakehead fish extract ointment undergoes a phase separation between the ointment base and the dispersed phase. This study aimed to determine the effect of variations in the concentration of CMC-Na and Carbopol as a binder on the ointment physical properties and to determine the best snakehead fish (Channa striata) extract ointment formulation.

\section{MATERIALS AND METHODS \\ Materials}

The research materials used were snakehead fish, kelulut honey, CMC-Na, Carbopol, methylparaben, propylparaben, propylene glycol, DMDM hydantoin, and adeps lanae. 


\section{Determinations}

In this study, snakehead fish (Channa striata) and kelulut honey (Trigona $s p$.) were determined in the Biology Laboratory, Biology Study Program, Faculty of Mathematics and Natural Sciences, Tanjungpura University, Pontianak, West Kalimantan.

\section{Methods}

\section{Processing of snakehead fish extract samples}

A total of $\pm 3 \mathrm{~kg}$ of snakehead fish that had been selected by purposive sampling (samples are taken with certain considerations) were carried out wet sorting by cleaning the scales and removing the head and stomach contents, the aim was to obtain clean snakehead fish meat and to minimize the presence of impurities. The snakehead fish was then rinsed again with clean water repeatedly until the soaking water was not cloudy, the aim was to eliminate impurities in the form of blood from the snakehead fish meat. Then the snakehead fish was weighed, the weight of snakehead fish meat was obtained as much as $2.912 \mathrm{~kg}$ or as much as $97.33 \%$ of the initial weight. The snakehead fish was then steamed for \pm 30 minutes at $60-70^{\circ} \mathrm{C}$. The steamed snakehead fish was wrapped in a flannel cloth or napkin and was then pressed with a hydraulic press. A thick liquid, a snakehead fish extract, was obtained from the pressing process with a weight of 650.6 grams (Eka and Rochima, 2016).

\section{Kelulut honey samples}

Kelulut honey was harvested during the dry season. The purpose of harvesting in the dry season was so that the honey obtained had low water content. The excessive water content found in kelulut honey can disturb the stability of the kelulut honey (Savitri et al., 2017).

\section{Preparation of ointments}

Kelulut honey and snakehead fish extract, were heated first by stirring them using a magnetic stirrer at a speed of $500 \mathrm{rpm}$ within 5 to 10 minutes until the temperature was around $50-60^{\circ} \mathrm{C}$. The temperature should not be too hot, because it would denaturate the protein and had higher risk to damage the protein content in the snakehead fish extract. Then CMC-Na was added slowly and left to expand. Carbopol was activated by continuously stirring it with honey and snakehead fish extract, then TEA was added to form a good gel mass. Each of the gelling agents and the active ingredients was stirred until they were homogeneous in the mortar and then DMDM Hydantoin was added slowly. The mixture was then added to a mortar containing adeps lanae which has been melted at a temperature of $70^{\circ} \mathrm{C}$, then stirred until it forms a good mass of ointment. Propylparaben and methylparaben which have been previously dissolved with propylene glycol were added to the mortar slowly until homogeneous. The preparation was stored in an ointment pot that aimed to prevent external factors such as air and light from affecting the preparation quality (Gorada et al., 2019). Ointment formulas can be seen in Table 1.

\section{Organoleptic test}

Organoleptic tests were carried out to determine the effect of adding gelling agents on the physical appearance of snakehead fish extract ointment by visually observing the shape, color, and odor of the preparation. This also relates to the acceptance of the ointment preparation in its application to the skin. Organoleptic testing will affect user comfort. The result preparation should have an attractive color, pleasant odor, and a soft texture on the skin (Orsat and Raghavan, 2006). 


\begin{tabular}{|c|c|c|c|c|c|c|}
\hline \multicolumn{7}{|c|}{ Table 1. Ointment formula } \\
\hline Ingredient & F1 & F2 & F3 & $\mathbf{F 4}$ & F5 & F6 \\
\hline $\begin{array}{l}\text { Snakehead fish } \\
\text { extract }\end{array}$ & $30 \%$ & $30 \%$ & $30 \%$ & $30 \%$ & $30 \%$ & $30 \%$ \\
\hline Kelulut honey & $30 \%$ & $30 \%$ & $30 \%$ & $30 \%$ & $30 \%$ & $30 \%$ \\
\hline CMC-Na & $3 \%$ & $4,5 \%$ & $6 \%$ & - & - & - \\
\hline Carbopol & - & - & - & $0,5 \%$ & $1 \%$ & $2 \%$ \\
\hline TEA & - & - & - & $0,5 \%$ & $1 \%$ & $2 \%$ \\
\hline Methylparaben & $0,18 \%$ & $0,18 \%$ & $0,18 \%$ & $0,18 \%$ & $0,18 \%$ & $0,18 \%$ \\
\hline Propylparaben & $0,02 \%$ & $0,02 \%$ & $0,02 \%$ & $0,02 \%$ & $0,02 \%$ & $0,02 \%$ \\
\hline Propylene glycol & $1,04 \%$ & $1,04 \%$ & $1,04 \%$ & $1,04 \%$ & $1,04 \%$ & $1,04 \%$ \\
\hline DMDM hydantoin & $1 \%$ & $1 \%$ & $1 \%$ & $1 \%$ & $1 \%$ & $1 \%$ \\
\hline Adeps lanae & ad $100 \%$ & ad $100 \%$ & ad $100 \%$ & $\begin{array}{c}\mathrm{ad} \\
100 \%\end{array}$ & $\begin{array}{c}\mathrm{ad} \\
100 \%\end{array}$ & ad $100 \%$ \\
\hline
\end{tabular}

\section{Homogeneity test}

The homogeneity test was carried out to know the homogeneity of the snakehead fish extract ointment preparation by applying the ointment to the transparent glass where the preparation in the container was taken from 3 parts (top, middle, and bottom). Homogeneity is indicated by the absence of coarse grains in the ointment preparation (Hasrawati et al., 2019).

\section{Spreadability test}

The spreadability test was carried out to determine the spreadability of the snakehead fish extract ointment when it was applied to the skin. 1 gram of ointment placed in the middle of a scale glass. A glass or other transparent material and weight (50, 100, 150 grams each) was placed on the ointment and left for 1 minute, then the diameter of the distribution of the ointment was recorded. The good spreadability of the ointment is between 5-7 cm (Mukhlishah et al., 2016).

\section{Adhesion test}

The adhesion test was carried out to determine the adhesion ability of the snakehead fish extract ointment preparation in its application to the skin. The adhesion test was carried out by weighing 0.25 grams of ointment, then placing it in a glass object whose width was determined. Another glass object was placed on top of the ointment and then pressed with a load of $1 \mathrm{~kg}$ for 5 minutes. The object-glass that sticks together was attached to the sticky power tester and removed with a load of 80 grams, then the time when the two slide glasses were released was recorded. Good adhesion of the ointment is more than 4 seconds (Mukhlishah et al., 2016).

\section{Data Analysis}

The test results of adhesion and spreadability of snakehead fish extract ointment were statistically analyzed using SPSS 21.0 with normality and homogeneity tests. If the data was homogeneous $(\alpha \geq 0.05)$ and normally distributed $(\alpha \geq 0.05)$, the statistical test will be continued with One Way ANOVA and Post Hoc. If not, the Kruskal-Wallis and Mann-Whitney nonparametric tests were performed. The data had a statistically significant difference when the parametric or non-parametric tests yielded $\alpha \leq 0.05$ (Hariningtyas, 2015). 


\section{RESULTS AND DISCUSSION}

Ointments were formulated to extend the contact time of the preparation against the wound so that the release of the drug from the base to the skin increases (Orsat and Raghavan, 2006). The ointments in this study were made in six different formulas with various concentrations of CMC$\mathrm{Na}(3 \%, 4.5 \%$, and $6 \%)$ and various concentrations of Carbopol $(0.5 \%, 1 \%$, and $2 \%)$ to compare which material was best in binding the water phase of snakehead fish extract to the ointment base. The active ingredients used in this study were snakehead fish extract (Channa striata) and kelulut honey (Trigona sp.). The results of the ointment can be seen in Figure 1.

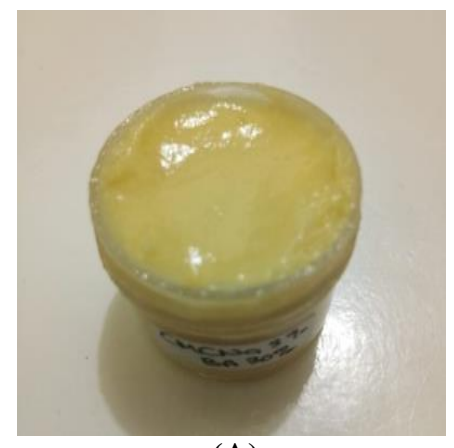

(A)

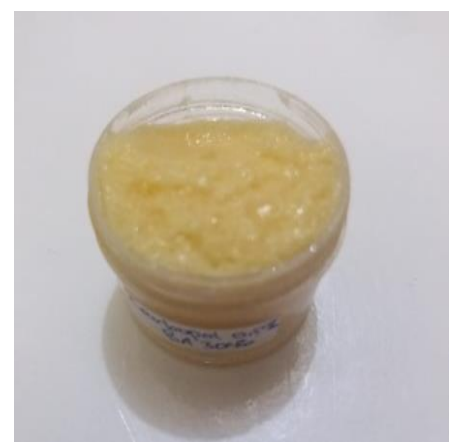

(B)

Figure 1. (A) The preparations ointment of snakehead fish extract with CMC-Na; (B) The preparations ointment of snakehead fish extract with carbopol

\section{Organoleptic test results of ointments}

Organoleptic test results on the color of the ointment with various concentrations of CMC$\mathrm{Na}$ and Carbopol showed a yellow color. This was because the color of adeps lanae, kelulut honey, and snakehead fish extract used were yellow. Organoleptic observations of the odor showed a distinctive smell of honey and fish extract. This was due to the concentration of kelulut honey and snakehead fish extract in the formula. Ointment with CMC-Na had a denser or harder texture than the ointment with Carbopol. This was because the gel produced by Carbopol shows synergistic characteristics of releasing the entangled liquid in the gel, allowing the liquid to move towards the surface and causing the surface of the preparation to become wetter (Astuti et al., 2017). These results indicate that the addition of the CMC-Na gelling agent can further improve the consistency or viscosity of the ointment compared to the Carbopol gelling agent.

\section{Homogeneity test results of ointments}

The ointment with various concentrations of CMC-Na and Carbopol had good homogeneity at the top, middle, and bottom of the container. A homogeneous ointment indicates the active substance has been distributed evenly and it is assumed that the active substance content will always be the same when used (Orsat and Raghavan, 2006).

\section{Spreadability test results of ointments}

Ointments with variations concentration of Carbopol had a larger distribution area than ointments with variations concentration of CMC-Na. The wet and soft surface of the ointment with Carbopol caused the ability to spread tend to be wider. Based on the data obtained, the good distribution power of the ointment was shown by Formula 4 (F4), ointment with $0.5 \%$ Carbopol, with an average spreadability of $5.09 \mathrm{~cm}$ after being given a load of 150 grams. This showed that even though this preparation fell into the good coverage range of the ointment, which is between 5$7 \mathrm{~cm}$, it took more effort to spread more widely on the skin. The data on the test results of the spreadability test can be seen in Table 2. Formula with Carbopol $0.5 \%$ (F4) had the highest average 
spreadability test result. This was also due to the concentration of the gelling agent used, where the higher concentration of the gelling agent added cause higher viscosity of the ointment so that the spreadability of the ointment will be smaller (Tanwar and Jain, 2012). In this study, Formula 4 (F4) was the formula with the lowest concentration of Carbopol, so this formula provide the most widespread test results compared to other formulas.

Table 2. Spreadability test results of snakehead fish extract ointments

\begin{tabular}{ccccc}
\hline \multirow{2}{*}{ Formulations } & \multicolumn{4}{c}{$\overline{\boldsymbol{x}} \pm \mathbf{S D}\left(\mathbf{c m}^{\mathbf{2}}\right)$} \\
\cline { 2 - 5 } & No burden & $\mathbf{5 0}$ grams & $\mathbf{1 0 0}$ grams & $\mathbf{1 5 0}$ grams \\
\hline F1 & $2.91 \pm 0.20$ & $3.42 \pm 0.19$ & $3.64 \pm 0.28$ & $3.88 \pm 0.36$ \\
F2 & $2.77 \pm 0.39$ & $3.28 \pm 0.39$ & $3.53 \pm 0.36$ & $3.79 \pm 0.39$ \\
F3 & $2.50 \pm 0.24$ & $3.01 \pm 0.24$ & $3.35 \pm 0.23$ & $3.54 \pm 0.23$ \\
F4* & $3.60 \pm 0.37$ & $4.12 \pm 0.37$ & $4.81 \pm 0.19$ & $5.09 \pm 0.62$ \\
F5 & $2.92 \pm 0.07$ & $3.44 \pm 0.07$ & $3.77 \pm 0.13$ & $3.97 \pm 0.14$ \\
F6 & $2.69 \pm 0.06$ & $3.21 \pm 0.06$ & $3.39 \pm 0.14$ & $3.61 \pm 0.15$ \\
\hline
\end{tabular}

Description: $*$ significantly different

\section{Adhesion test results of ointments}

All snakehead fish extract ointment preparations had good adhesion, which was more than 4 seconds. The result of the ointment adhesion test showed that the ointment with $0.5 \%$ Carbopol (F4) formula, had the lowest adhesion power, with an average adhesion of 229 seconds. These results were related to the texture and spreadability of the Carbopol $0.5 \%$ (F4) formula ointment, where it had a soft texture and had the greatest spreadability among other formulas, so it had the lowest adhesion. This is following the research conducted by (Dewi and Saptarini, 2016), where the lower concentration of the gelling agent used, the more it will increase the spreadability and reduce the adhesion of the preparation. The data on the test results of the adhesion test can be seen in Table 3. Ointment with Carbopol 0.5\% (F4) was significantly different from other formula groups. Although they were significantly different, the six formulas still have good adhesion, where all formulas had adhesion of more than 4 seconds (Astuti et al., 2017).

Table 3. Adhesion test results of snakehead fish extract ointments

\begin{tabular}{cc} 
Formulations & Adhesion $\overline{\boldsymbol{x}} \pm \mathbf{S D}$ (Seconds) \\
\hline F1 & $1800 \pm 0$ \\
F2 & $1800 \pm 0$ \\
F3 & $1800 \pm 0$ \\
F4 & $229 \pm 217.49^{*}$ \\
F5 & $1800 \pm 0$ \\
F6 & $1800 \pm 0$ \\
\hline Description: $*$ significantly different
\end{tabular}

\section{CONCLUSION}

Based on the ointment formulation of snakehead fish extract, ointments with variable concentration of $\mathrm{CMC}-\mathrm{Na}$ have denser texture and consistency than ointments with variable concentration of Carbopol; ointments with $0.5 \%$ Carbopol (F4) had the largest average dispersion and the smallest average adhesion than other formulas. The best formulation was shown by the 
Carbopol $0.5 \%$ (F4) formula, where the average spreadability with a load of $150 \mathrm{~g}$ was $5.09 \mathrm{~cm}$ and the average adhesion was 229 seconds.

\section{REFERENCES}

Andrie, M., \& Taurina, W. (2017). Uji aktivitas antibakteri secara in vivo berbagai ekstrak tanaman obat dalam bentuk sediaan salep, krim, dan gel pada tikus putih jantan (Rattus norvegicus) galur wistar. Dipa Untan.

Andrie, M., \& Taurina, W. (2018). Uji aktivitas antibakteri beberapa tanaman obat secara in vitro. Dipa Untan.

Astuti, D. P., Husni, P., \& Hartono, K. (2017). Formulasi dan uji stabilitas fisik sediaan gel antiseptik tangan minyak atsiri bunga lavender (Lavandula angustifolia Miller). Farmaka, 15(1), 176-184

Dewi, C. C., \& Saptarini, N. M. (2016). Hidroksi propil metil selulosa dan karbomer serta sifat fisikokimianya sebagai gelling agent. Farmaka, 14(3), 1-13

Eka, B., Junianto, \& Rochima, E. (2016). Pengaruh metode rendering terhadap karakteristik fisik, kimia dan organoleptik ekstrak kasar minyak ikan Lele. Jurnal Perikanan Kelautan, 7(1), 1-5

Gadekar, R., Saurabh, M. K., Thakur, G. S., \& Saurabh, A. (2012). Study of formulation, characterisation and wound healing potential of transdermal patches of Curcumin. Asian Journal of Pharmaceutical and Clinical Research, 5(SUPPL.4), 225-230

Garlen, D. (1996). Toothpastes. In Pharmaceutical Dosage Forms: Dysperse Systems (pp. 423442). Marcel Dekker Inc

Gorada, Taurina, W., \& Andrie, M. (2019). Formulasi sediaan salep madu kelulut ( heterotrigona itama ) dan fase air ekstrak ikan gabus ( Channa Striata ). Jurnal Mahasiswa Farmasi Fakultas Kedokteran UNTAN, 4(Vol 4, No 1 (2019): Jurnal Farmasi Kalbar), 1-7. http://jurnal.untan.ac.id/index.php/jmfarmasi/article/view/33514

Gunawan, N. A. (2017). Madu : efektivitasnya untuk perawatan luka. Iai, 44(2), 138-142

Hariningtyas, R. A. (2015). Pengaruh asimetri informasi terhadap senjangan anggaran pendahuluan. Jurnal Nominal, IV(2), 73-87

Hasrawati, A., Famir, Y., \& Mursyid, A. M. (2019). Formulasi dan evaluasi salep ekstrak daun gulma siam ( Chromolaena odorata L .) dengan variasi basis salep Formulasi dan evaluasi salep ekstrak daun gulma siam ( Chromolaena odorata L .) dengan variasi basis salep. AsSyifaa Jurnal Farmasi, 11(01), 55-60

Mukhlishah, N. R. I., Sugihartini, N., \& Yuwono, T. (2016). Daya iritasi dan sifat fisik sediaan salep minyak atsiri bunga cengkeh (Syzigium Aromaticum) pada basis hidrokarbon. Majalah Farmasetik, 12(1), 372-376

Orsat, V., \& Raghavan, G. S. V. (2006). Dehydration technologies to retain bioactive components. In Functional Food Ingredients and Nutraceuticals: Processing Technologies (pp. 173-192). CRC Press. https://doi.org/10.1201/9781420004076.ch7

Rowe, R., Sheskey, P., \& Quinn, M. (2009). Handbook of Pharmaceutical Excipients. In London: Vol. E.28 (6th editio)

Sabale, P., Bhimani, B., Prajapati, C., \& Sabalea, V. (2012). An overview of medicinal plants as wound healers. Journal of Applied Pharmaceutical Science, 2(11), 143-150. https://doi.org/10.7324/JAPS.2012.21127

Savitri, N. P. T., Hastuti, E. D., \& Suedy, S. W. A. (2017). Kualitas madu lokal dari beberapa wilayah di kabupaten Temanggung. Buletin Anatomi Dan Fisiologi, 2(1), 58. https://doi.org/10.14710/baf.2.1.2017.58-66

Strauer, B. E. (2008). Acute myocardial infarction. Der Internist, 49(9), 1022-1022. https://doi.org/10.1007/s00108-008-2191-z

Tanwar, Y. S., \& Jain, A. K. (2012). Formulation and evaluation of topical diclofenac sodium gel using different gelling agent. Asian Journal of Pharmaceutical Research and Health Care, $4(1), 1-6$ 
Zulfa, E., Indah, F., \& Murukmihadi, M. (2017). Optimasi Cmc-na dan karbomer sebagai pengikat pada formula pasta gigi triklosan secara Sld. E-Publikasi Fakultas Farmasi, 2012, 156-162 